\title{
Fruit Fly, Anastrepha edentata Stone (Insecta: Diptera: Tephritidae) ${ }^{1}$
}

H. V. Weems, Jr. ${ }^{2}$

\section{Introduction}

Anastrepha edentata Stone has been collected in the Florida keys in every month of the year, but its host plants still are unknown. It is one of six species of fruit flies of the genus Anastrepha which occur in Florida or which have been established in Florida at some time. According to Division of Plant Industry records, it has not been found in Florida since 1936. There is a possibility that this species has not survived in Florida. It is not considered to be of economic importance anywhere within its range.

\section{Distribution}

Known in Florida and Puerto Rico. In Florida this species has been recorded from Key Largo Key to Key West. There is a record for Redlands, Dade County, Florida. The type locality is Key Largo, Florida.

\section{Life History}

The life history of Anastrepha edentata has not been ascertained.

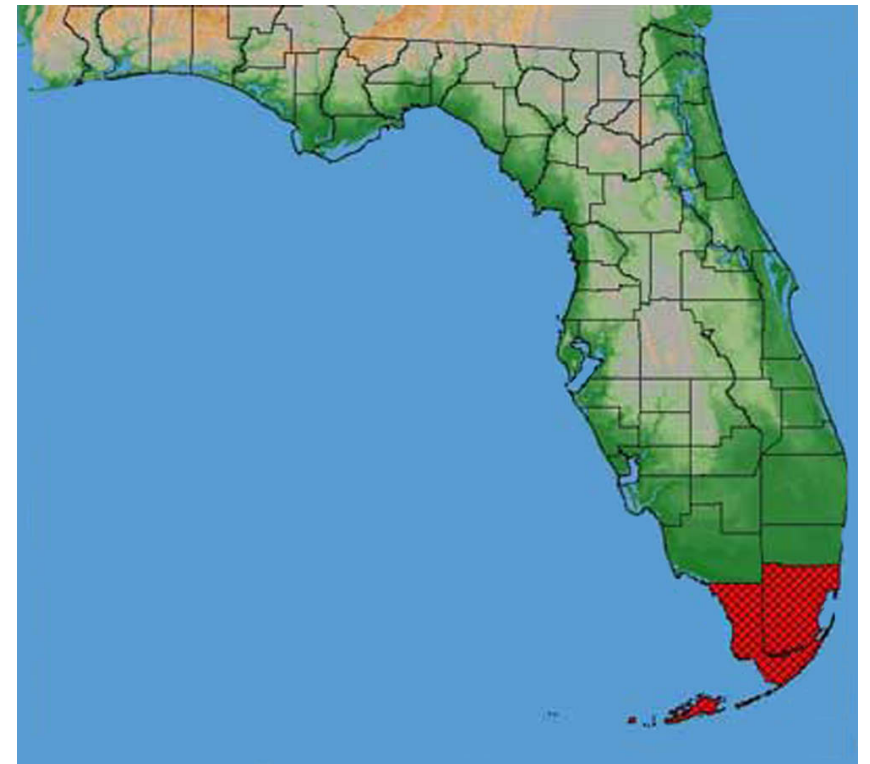

Figure 1. Distribution of the fruit fly, Anastrepha edentata Stone, in Florida. Credits: G.J. Steck and B.D. Sutton, Division of Plant Industry

\section{Identification}

Small yellow-brown fly with patterned wings; the female with a long, slender ovipositor sheath and very slender ovipositor, readily distinguishing it from

\footnotetext{
1. This document is EENY-264 (originally published as DPI Entomology Circular 76), one of a series of Featured Creatures from the Entomology and Nematology Department, Florida Cooperative Extension Service, Institute of Food and Agricultural Sciences, University of Florida. Published: January 2002. This document is also available on Featured Creatures Website at http://creatures.ifas.ufl.edu. Please visit the EDIS Website at http://edis.ifas.ufl.edu. Additional information on these organisms, including many color photographs, is available at the Entomology and Nematology Department website at http://entnemdept.ifas.ufl.edu/.

2. H. V. Weems, Jr., Florida Department of Agriculture and Consumer Services, Division of Plant Industry, Gainesville, FL.
} 
other species recorded from Florida. The wing pattern is partly yellowish, partly brownish infuscated, and is somewhat variable. In some specimens the inverted $\mathrm{V}$ band is connected at its apex with the $\mathrm{S}$ band on the anterior portion of the wing, while in others the inverted $\mathrm{V}$ band is separated from the $\mathrm{S}$ band; usually it is complete and joined to the $\mathrm{S}$ band. The costal and 3 bands are widely separated on vein $\mathrm{R} 4+5$ but on vein $\mathrm{R} 2+3$ they vary from widely separated to connected here, or all of R1 infuscated between the two bands. Head yellow with frontal bristles and ocellar triangle black; antennae yellow. Humerus with a very narrow median strip widening abruptly on mesoscutum posteriorly, lateral stripes from transverse suture to scutellum, and scutellum pale yellow; metanotum entirely yellow brown. Macrochaetae black; pile pale yellow brown. Legs yellow.

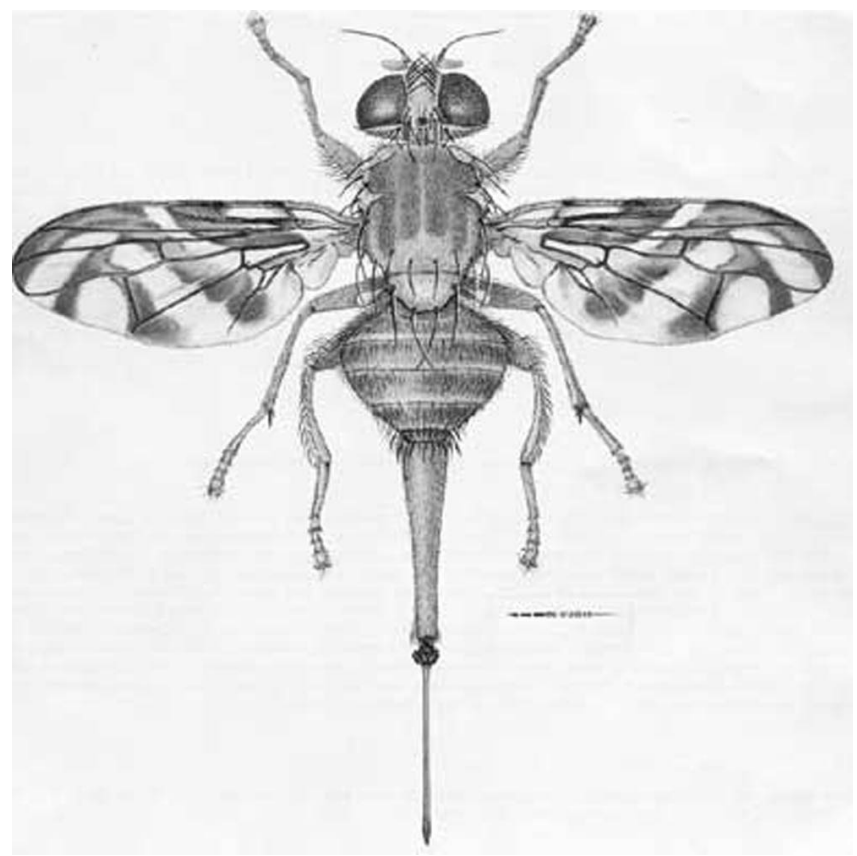

Figure 2. Adult female Anastrepha edentata Stone, a fruit fly. Credits: Division of Plant Industry

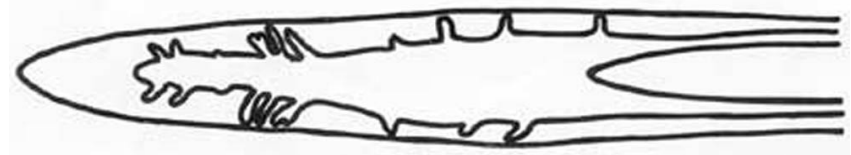

Figure 3. Ovipositor tip. Credits: Division of Plant Industry

\section{Hosts}

Unknown.

\section{Selected References}

State Plant Board of Florida Eleventh Biennial Report for the period July 1, 1934-June 30, 1936. Jan. 1937. p. 20-21. Anastrepha sp. "F," Brown.

Stone A. 1942. The fruit flies of the genus Anastrepha. U.S. Department of Agriculture Miscellaneous Publication No. 439, Washington, D.C. $112 \mathrm{p}$. 